\title{
Recenzja monografii Piotra Alexandrowicza Kanonistyczne uzasadnienie swobody umów w zachodniej tradycji prawnej. Poznań: Wydawnictwo Naukowe UAMM, 2020, stron 333
}

\begin{abstract}
Review of Piotr Alexandrowicz's Book Canonistic Justification of Freedom of Contract in the Western Legal Tradition. Poznań: Wydawnictwo Naukowe UAM, 2020, 333 Pages

The inspiring monograph of Piotr Alexandrowicz entitled "Canonistic Justification of Freedom of Contract in the Western Legal Tradition" clearly shows that the true creators of freedom of contract were not ancient Roman jurists or emperors, but medieval canonists. Based on Christian moral theology, they built the unique doctrine of obligations without which it is quite difficult to imagine contemporary legal transactions. Their thought was subsequently taken up and further developed by modern thinkers.
\end{abstract}

Keywords: history of canon law, law of obligations, freedom of contract, Western Legal Tradition

Słowa kluczowe: historia prawa kanonicznego, prawo zobowiązań, swoboda umów, zachodnia tradycja prawna

Piotr Alexandrowicz jest młodym uczonym o imponującym dorobku, specjalizującym się w badaniu historii prawa kanonicznego w ujęciu porównawczym. Posiada wykształcenie prawnicze, kanonistyczne oraz teologiczne. Przed wydaniem recenzowanej pracy dał o sobie usłyszeć w serii znakomicie przyjętych artykułów oraz w monografii Znaczenie dekretatu Intelleximus (X 5.32.1) w procesie recepcji prawa rzymskiego w XIII-wiecznej kanonistyce (Poznań-Kraków 2018). W chwili obecnej jest to jeden z niewielu przedstawicieli młodego pokolenia uczonych w Europie Środkowej, który posiada odpowiednie 
przygotowanie do naukowego analizowania problemów związanych $\mathrm{z}$ drogami przenikania się prawa kanonicznego i świeckiego.

To łaska, że polskie środowisko naukowe może cieszyć się jego obecnością, ponieważ badania nad historią prawa kanonicznego przeżywają zauważalny kryzys. Ma on swoje uwarunkowania historyczne, ale nie tylko. Owszem, Europa wciąż zmaga się ze skutkami decyzji podejmowanych w czasach oświecenia, kiedy to podczas wielkiej antykościelnej kampanii oraz $\mathrm{w}$ ramach radykalnej realizacji postulatu oddzielenia państwa od Kościoła, wylano dziecko razem z kąpielą, z premedytacją „zapominając” o przemożnym wpływie prawa kanonicznego na kształtowanie prawnego obrazu współczesnego świata. W naszym kraju sytuację dodatkowo utrudnia smutna spuścizna okresu PRL-u, nadal rzutująca na postrzeganie prawa kanonicznego i jego dorobku. Niemniej trudno również zaprzeczyć, że zajmowanie się historią prawa kanonicznego, jego ewolucją, stopniowym wykuwaniem i kształtowaniem przez nie pojęć oraz nauczeniem, należy do zadań żmudnych i niewdzięcznych. Szansę na zgłębienie geniuszu myśli kanonistycznej już na starcie niweczy powszechna nieznajomość łaciny oraz coraz słabsza znajomość języków obcych. Na samym zaś końcu długiej listy „przeszkód” lokuje się tymczasem niezmienny w swej istocie, a przez to być może odstręczający badaczy „postępowych”, fakt, że nie da się prowadzić sensownych badań na tym polu bez odniesienia do teologicznej refleksji Kościoła.

Z tym większą radością należy więc przyjąć, że polskie piśmiennictwo wzbogaciło się o rzetelne studium Piotra Alexandrowicza pt. Kanonistyczne uzasadnienie swobody umów w zachodniej tradycji prawnej. Zapoznanie się z jego trzema rozdziałami (I: „Argumentacja średniowiecznych kanonistów na rzecz zaskarżalności wszystkich umów”; II: „Kanonistyczna idea związania danym słowem w okresie nowożytnym”; III: „Aktualność średniowiecznej argumentacji kanonistów a współczesne teorie umów”) nie pozostawia większych wątpliwości odnośnie do tego, kto stoi za celebrowaną obecnie zasadą swobody umów. Pozwala również w pełni dostrzec w prawie kanonicznym jeden z najważniejszych filarów euroatlantyckiej kultury prawnej.

Obecnie zasada swobody umów stanowi jeden z filarów obrotu prawnego w państwach cywilizowanych. W Polsce jej obowiązywanie poza art. $353^{1}$ Kodeksu cywilnego doktryna wyprowadza $\mathrm{z}$ art. 31 ust. 1 i 2 oraz art. 20 i art. 22 Konstytucji RP. W okresie II RP zabezpieczał ją m.in. art. 55 Kodeksu zobowiązań. Wszelkie ograniczenia ingerujące swobodę obrotu prawnego i ograniczające wolność gospodarczą natychmiast ściągają na siebie uwagę, i słusznie, gdyż nasz kraj doświadczył już skutków ręcznego sterowania gospodarką i chciałby możliwie jak najczęściej unikać błędów popełnianych w przeszłości. Wydawać by się więc mogło, że trudno będzie znaleźć jakiekolwiek związki pomiędzy tak ,przyziemnym” i konkretnym zagadnieniem jak swoboda umów a „bujającym w obłokach" prawem kanonicznym. Treść recenzowanej monografii temu przeczy. Paradoksalnie, to pragmatyczni Rzymianie - których myśl zwykle służy nam jako tertium comparationis - nigdy nie zdobyli się na dogmatyczne stworzenie, a następne naukowe opracowanie zasady, bez której dziś nie wyobrażamy sobie obrotu prawnego. Zrobili to średniowieczni kanoniści wspierani przez teologów.

W realiach antycznych obowiązywał nominalizm kontaktowy, który skutecznie blokował proces uwolnienia się umów, a także uniemożliwił stworzenie przez rzymskich jurystów ogólnej ich teorii. Postanowień umów nazwanych w średniowieczu „gołymi” 
(nuda pacta), czyli tych, które nie mieściły się w szablonie prawa obywatelskiego (ius civile), nie dało się skutecznie egzekwować przed rzymskimi sądami. Dopiero kanoniści, odwołując się m.in. do postulatów formułowanych przez teologię moralną, postawili tezę obowiązywalności wszystkich porozumień. Rozwiązanie to okazało się rewolucyjne dla dalszego rozwoju prawa zobowiązań. Stało się ono przedmiotem niezliczonych badań i odniesień w piśmiennictwie późniejszym. Kiedy więc w wiekach XIX i XX nowocześni ustawodawcy zdecydowali się zamknąć zasadę swobody umów w krótkich przepisach o abstrakcyjnym charakterze, dysponowali kilometrami materiałów i niezliczoną liczbą argumentów zbudowanych na fundamencie kanonistycznym.

Recenzowana monografia znakomicie obrazuje proces wykształcenia się kanonistycznej argumentacji uzasadniającej swobodę umów, a następnie interakcję, w jaką prawo kanoniczne weszło w tej materii z porządkami świeckimi. Swój wywód Autor prowadzi powoli i z uwagą. Omawia nie tylko poglądy poszczególnych kanonistów i legistów, ale również streszcza krótko ich życiorysy, umiejętnie lokując je na tle epoki, w której żyli. Przez to praca przyjmuje charakter nie tyle kompilacji, ile znakomicie opracowanej syntezy badanego zagadnienia.

Niezależnie od produkowanych obecnie na poczekaniu teorii uzasadniających zasadność swobody umów, jej rzeczywistą podstawą, którą ubrali w kunsztowne teorie średniowieczni kanoniści, a następnie rozwinęli ich następcy, jest mocno ugruntowany w chrześcijańskim nauczaniu postulat zachowania uczciwości w codziennym życiu. Monografia Piotra Alexandrowicza jest jedynym znanym mi dziełem, które w tak oczywisty i zarazem skrupulatny sposób tego dowiodło. 